\title{
IMPLEMENTATION OF PROJECT ORIENTED PROBLEM-BASED LEARNING (POPBL) MODEL INTEGRATED WITH STEM TO ENHANCE JUNIOR HIGH SCHOOLSTUDENTS' SCIENCE CONCEPT MASTERY
}

\author{
Eliyawati $^{1}$, Yayan Sanjaya ${ }^{2}$, AS Ramdani ${ }^{3}$ \\ ${ }^{1}$ Prodi Pendidikan IPA, Universitas Pendidikan Indonesia, Jl. Dr. Setiabudi no 229, Bandung 40154, Indonesia \\ ${ }^{2}$ Departemen Pendidikan Biologi, Universitas Pendidikan Indonesia, Jl. Dr. Setiabudi no 229, Bandung 40154, Indonesia \\ ${ }^{3}$ SMP Karya Prestasi Mandiri JL Babakan Loa No 44 Padalarang,, Bandung Barat, 40553, Indonesia \\ 1 eliyawati@upi.edu
}

Accepted: September 23, 2020

Published: October 31, 2020

DOI: https://doi.org/ 10.21107/jps.v7i2.8260

\begin{abstract}
The low ability of students to solve problems is in line with the low mastery of science concepts. In this study, Science, Technology, Engineering, and Mathematics (STEM) integrated Project Oriented Problem Based Learning (POPBL) learning models were implemented to improve the mastery of science concepts of junior high school students, especially on the topic of Environmental Pollution. The method used was a mixed-method. The STEM integrated STB learning model design framework consists of 3 stages: Onset Stage, Execution Stage, and Closure Stage. The concept of students is emphasized at the onset stage in the case study dissemination phase. In this phase, students analyze problems based on articles provided by the teacher. The more understanding the material, the more critical students will explore existing issues and find logical solutions to those problems. The results showed that there was a difference between the average pretest and posttest learning outcomes $(t=-5,660 ; \mathrm{df}=53$; Sig. (2-tailed) $=0,000)$. This indicates an increase in junior high school students' science concepts mastery after using the STEM integrated POPBL Learning Model. Improving students' mastery of concepts using a STEM integrated POPBL learning model is still in the low category with n-gain $=0.17$. Although still in the low category, the POPBL learning model with the STEM approach can be optimized to improve students' mastery of concepts and skills on other science topics.
\end{abstract}

Keywords: science concept, learning model, POPBL, STEM.

\footnotetext{
${ }^{1}$ Corresponding Author
} 


\section{Introduction}

Economic development is accelerating in line with the emergence of a new economic potential, namely the creative economy in the $21 \mathrm{st}$ century. The creative economy is an economy that is based on creative and innovative ideas. The economic wave that is now evident in Indonesia. Incidentally, Indonesia has many creative people who can produce distinctive and reliable creative industrial products. So, it is only natural for both the government and industry players to pay serious attention to the creative industry's development. The blueprint for the innovative industry development plan focuses on 14 sub-sectors of the creative industry, namely architecture, design, fashion, film, video and photography, crafts, computer services and software, music, the art market, publishing and printing, advertising, interactive games, research and development, performing arts, as well as television and radio (Ministry of Industry of the Republic of Indonesia, 2016).

Education in Indonesia must be adjusted to pay attention to this economic development so that future students can become an integral part of the creative economy era. Primary to higher education must provide education that makes students creative and innovative (Ruhizan, Ramlee, \& Azami, 2014). Education plays a significant role in ensuring future generations are capable and well equipped to meet the challenges of the $21 \mathrm{st}$ century. All over the world, educators have realized that children need more than reading, hypnotic \& arithmetic skills when they leave school. The need to create quality human beings is more important than ever. Therefore, to compete in the global market, Indonesia needs to produce new people capable of using technology and contributing to technology (Wicaksono, 2020). In other words, a workforce skilled in innovating, finding, and solving problems.

The job sector needs a workforce with a market value in facing the challenges of the $21 \mathrm{st}$ century. These skills include problem-solving skills, critical and innovative thinking, and teamwork (Yasin \& Rahman, 2011). Therefore, students cannot be judged only on academic achievement, but they also need to master 21 stcentury skills. Specific skills in the 21 st century include critical thinking skills, problem-solving abilities, metacognition, communication and collaboration skills, creativity, innovation, literacy of information, media, technology, and so on (Zubaidah, 2017). 21st-century skills are essential to development because they are needed in solving scientific problems in everyday life (Siswanto, 2020). The development of 21 st-century skills cannot be separated from an understanding of a science concept. Students' ability to think divergent, think out of the box, expand new ways of thinking with new ideas, and solve a problem to learn certain concepts are ways to develop 21stcentury skills.

The low level of mastery of science concepts is a reality that has happened to some Indonesian students (Ramdani, A., Jufri, A., Jamaluddin, J., \& Setiadi, D., 2020; Amarudin, 2020; Widiasari \& Sumantri, 2020). One factor is influenced by teachers' teaching styles, who are still teachercentered (Widiasari \& Sumantri, 2020). Science learning is still dominated by lecture methods that cannot help students improve their thinking skills. This learning effect encourages students to learn through memorization so that they quickly forget the concepts they receive. This shows that the learning that has been carried out is less effective in maintaining students' mastery of concepts (Pujani, Suma, Sadia, \& Wijaya, 2018). Teachers rarely use methods to build knowledge for students, directing students to explore more material independently, making learning concepts more meaningful based on problems (Hasanah, Hasruddin, \& Yus, 2018).

If the mastery of science concepts is low, so will the 21st-century students' skill level. Therefore, these facts in Indonesia need to be a challenge for a teacher to find the right learning model to improve students' mastery of science concepts. For example, the combined learning model between Problem Based Learning (PBL) and Project-Based Learning (PjBL) is called Project Oriented Problem Based Learning (POPBL).

PBL is a learning model that challenges students to learn and learn more, working with groups to find solutions to real problems, which are used to link students' curiosity in analysis and initiatives on the subject matter (Hasanah, Hasruddin, \& Yus, 2018). The PBL learning model emphasizes activities that must interact more with objects or events. In this case, students can have flexible knowledge, find the most effective way to solve problems, independent learning skills, collaboration, and intrinsic motivation to understand the concept is expected to be stronger (Wardani, 2017). Research using the PBL learning model has been widely carried out to improve mastery of science concepts (Rahman, Khaeruddin, \& Ristiana, 2020; Wulandari, Kadir, La Fua, \& 
Zainuddin, 2020; Devi \& Bayu, 2020; Wijayama, 2020; Putri, Rusyati \& Rochintaniawati, 2018).

Another learning model is $\mathrm{PjBL}$, which refers to direct experiences carried out by students and social interactions to build mutual understanding. Learning experiences come from practicing in the laboratory, investigating findings, and solving problems by creating projects. The principles of $\mathrm{PjBL}$ are the attainment of knowledge through patience and flexibility, learning with practical experience, and applying newly guided knowledge to new situations and conditions (Mahasneh \& Alwan, 2018). Several studies state that mastery of the science concept using the PjBL learning model has increased (Andanawarih, Diana, \& Amprasto, 2019; Yamin, Permanasari, Redjeki, \& Sopandi, 2017).

The combination of the two learning models, PBL and PjBL, called POPBL is expected to be used as an alternative learning model where student-centered through learning a project in overcoming a surrounding problem (Ibrahim \& Halim, 2013; Meehan, Lawlor, \& McLoone, 2014; Moesby, 2005; Mohamed, Jubadi, \& Zaki, 2011; Ruhizan et al., 2014; Wan Nor Fadzilah et al., 2016; Yasin \& Rahman, 2011). POPBL tries to cultivate students' ability to learn actively, think critically, and solve problems through an instruction process that focuses on practical tasks. It also encourages students to have group discussions. The result of the POPLB learning model is a product that has a STEM connection. The science concept chosen is a science concept that is very relevant and can explain everyday life phenomena, including environmental pollution. Misunderstanding of the concept of environmental pollution has created temporary assumptions for each student. This is reinforced by Valeiras \& Godoy (2007) research, which identifies misconceptions about the topic of environmental pollution, making students confused about abstract issues such as the ozone layer, the process of air pollution, soil pollution, and noise pollution. Therefore, the researcher tries to implement the STEM integrated Project Oriented Problem Based Learning (POPBL) learning model in increasing the mastery of science concepts in junior high schools on the topic of environmental pollution.

\section{Research Methods}

The method used in this study is a mixedmethods research method that involves the use of quantitative methods and qualitative methods together (Fraenkel, 2008). Quantitative research methods are used to determine the extent to which students' mastery of science concepts in junior high school uses the POPBL learning model, which is integrated with STEM. In contrast, the learning model's implementation data and student responses to the STEM integrated POPBL learning model will be analyzed qualitatively. The research design used is the one group pretest-postest design in which the measured class will be given a test before and after treatment (Fraenkel, 2008). The research subjects were 54 junior high school students at a junior high school in West Bandung. This research's data collection instruments include lesson plans, learning observation sheets, and multiple-choice tests. Observation sheets are used to capture information directly about student and teacher activities during the learning process. The observation sheets are prepared according to the STEM integrated POPBL Learning Model steps in the lesson plan. The multiple-choice test was used to measure the mastery of science concepts in junior high school, amounting to 18 multiple choice questions with details on the cognitive level as follows: five memory questions ( $\mathrm{C} 1$ ), five understanding questions $(\mathrm{C} 2)$, ten application questions (C3), ten analyzing questions (C4), five questions evaluate (C5), and five questions create (C6). Student learning outcomes, which included pretest and posttest data, were analyzed using SPSS 16.00, including normality tests, paired sample statistics, paired sample correlations, and paired sample tests.

\section{Result and Discussion}

The POPBL learning design framework consists of 3 stages: Onset Stage, Execution Stage, and Closure Stage. Based on Figure 1, the learning stage at the onset stage is for learning preparation with POPBL implementation. At the onset stage, a survey of student learning styles was carried out, followed by project groups consisting of 4 to 5 people in one group. Furthermore, students are asked to discuss problems that have been given by the teacher with predetermined topics. Students are asked to brainstorm with their groups after the issues to be addressed have been determined. The next stage is to analyze the problem and determine the solution that will be made using the project.

The execution stage is carried out by the real world's actual implementation, applied to the learning model. The execution stage is divided into four processes: requirements, analysis and design, development, and testing. In the requirements process, students are asked to determine the problems raised and then resolved based on the case study dissemination and brainstorming results 


\section{Eliyawati, Sanjaya, Ramdani}

at the onset stage. Analysis and design process after the problem is determined. Students propose solutions to predetermined problems. Students are asked to make a project description that will be made, starting from planning, implementing, testing, and evaluating the project. After students analyze and make project design plans, students create projects and development projects following the designs that have been designed by each group. The final process is project testing and project development aimed at correcting the weaknesses of the project.

During the four processes, it is demanded to carry out phases, including 1) Project Milestone Reporting every actual incident in the form of a written report; 2) Meeting Logs - Hold meetings both during class hours and group work outside of class hours; 3) Team Peer review - Report and evaluate performance among students in each group (peer-review); 4) Lecturer Evaluation Evaluation conducted by the teacher; and 5) Team
Reflection - Reflections or evaluations carried out by each group.

The POPBL learning phase is closely related to the four process circles implemented (see Figure 1). Running this execution stage is an essential part of the POPBL model. The project created is a product related to Science, Technology, Engineering, and Mathematics (STEM), so that the learning approach used in this POPBL learning model is the STEM approach. The STEM approach's most important concept is integrating goals from various disciplines to solve real-world problems (Sanders, 2009). This STEM approach perspective involves science, Technology, Engineering, and Mathematics as one unit. It teaches an integrated discipline as a cohesive whole and tends not to separate disciplines, as seen in chemistry, physics, mathematics, or biology. Students carry out a post-test and review at the last stage or the closure stage to confirm the concept of a project made by students. Then, it ends with an exit survey in the form of a questionnaire.

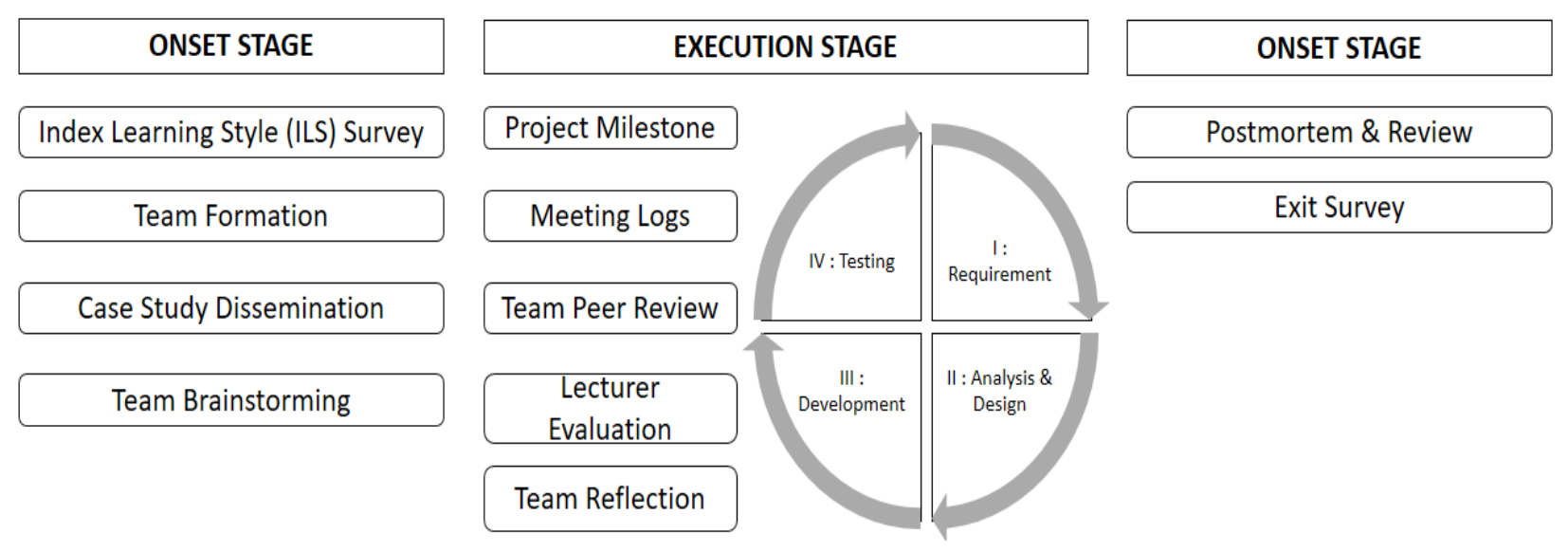

Figure 1. Framework POPBL Model (Ibrahim, 2013)

Implementing the STEM integrated POPBL model is not all carried out by the teacher because it is adjusted to student's and schools' conditions that apply this learning model. Starting from the onset stage as the initial preparation stage in the POPBL model, the teacher does not apply student learning style surveys because it emphasizes concept mastery as the focus of research using the STEM-integrated POPBL learning model. Instead, the teacher applies the pre-test to measure students' mastery of concepts regarding the material to be discussed. The groups' formation based on the pretest students' results grouped the highest, medium, and smallest scores. This is done so that all groups have the same ability to work on the project. Each group contains 4 to 5 students who then discuss determining the chairman, secretary, treasurer, and project expert staff.

After forming the group, it was continued with a discussion of the problem. In this case, the teacher gave an article on air pollution caused by an Air Conditioner (AC), which turned out to worsen air conditions with its effects. Each group brainstorms to find the core of the problem and find solutions to these problems. At this stage, students are given a workbook that guides each group to work on a project. The second meeting of students tried to analyze the data using a pollution sensor that had been prepared. Every 2 minutes, the students wrote down the data shown on their cell phones in the form of changes in temperature, carbon dioxide, and monoxide levels. Students are 
asked to report the results of their observations and analyzes in their notebooks.

Execution stage, students are faced as if they are facing the real situation at the 3rd meeting. Students are asked to report work results to the teacher through writing on the workbook and verbally or directly. In the first process of requirements, students determine the problems to be analyzed based on the data obtained at the second meeting. The issues discussed are limited to air pollution only and focus on the impact of air pollution that students can feel, such as hot temperatures and unpleasant odors caused by the factory next to the school.

In the second process of analysis and design, students are asked to draw a project design that will be made on the workbooks. Each group determines what tools and materials will be used during project development. As for items purchased by students, they must use a purchase note. Students analyze the positive and negative impacts of each material used before the project is done. In the 3rd meeting (end of the session), the group leader reports his work to the teacher outside of class hours.

Next, in the 3rd process, project creation and development, each group begins to do a project with materials that each group has brought for 2 hours of lessons. Teachers supervise the progress of these activities. In practice, students are required to complete a project at three meetings. At each project progress, the teacher will evaluate based on the report from the group leader. A common problem that occurs is students are confused about determining the contents of environmentally friendly air conditioners that they will make. In developing the tool, students criticized many things, such as how air pollution can increase temperature. The 4th process is testing or project testing. At this stage, each group is examined by the teacher for project performance, and then the teacher will provide input related to the project that has been made. Students collect documentation of project developments and workbooks that are used as assessment materials at the closure stage. During the execution stage, four process circles were carried out well and followed 5 phases, such as peer review, teacher evaluation, and reflection for each group. This can make the group perform maximally, and students participate actively in every group work carried out.

Closure stage, students, carry out a project presentation session and posttest. The teacher assesses students' final projects using a rubric.
Each group presents their project and tries the project in front of the class to prove their project. Each group may ask questions to the group that presents their work.

The main research variable in this study is to measure the increase in students' mastery of concepts on the topic of Environmental Pollution. The student concept emphasizes the onset stage in the case study dissemination phase. In this phase, students analyze problems based on the articles provided by the teacher. The more they understand the material, the more critical they will explore existing problems and find logical solutions. Therefore, understanding science is essential for everyone, not just scientists. Students need to understand every subject studied in school. Students understand if they build a correlation between the new knowledge they carry with their previous knowledge (Anderson, 2001).

The increase in students' mastery of concepts based on the results of the n-gain from the pre-test and post-test data showed a low category with an n-gain of 0.17 (Table 1). This indicates that there is an increase, but the increase that occurs is very small. The interesting thing from table 1 is that some students showed the stability of the value between the pre-test and posttest scores $(\mathrm{n}$-gain $=0)$, and some even showed a decreasing value marked by the value of $n$-gain $=$ negative. After investigating why this happens, it turns out that students cannot understand the phenomenon of environmental pollution that occurs. The teacher's task in this discussion session also does not lead to the correct opinion because it is too hasty in completing the topic being discussed.

The learning style analysis stage at the initial stage was not carried out, even though this is very important to optimize students' mastery of concepts. When it is not done, it will impact the modest learning process without paying attention to the learning style so that the results of the learning process will vary when accepted by students. Further analysis regarding the students' conceptual mastery was carried out by means of a significance test on the pre-test and post-test scores. We tested the paired sample statistics, the paired sample correlations, and the paired sample test. 
Eliyawati, Sanjaya, Ramdani

Table 1. Results of Students' Mastery of Science Concepts Using STEM Integrated POPBL Model

\begin{tabular}{|c|c|c|c|c|c|c|}
\hline No & Name & Pretest & Posttest & Gain & N-Gain & Category \\
\hline 1 & $\mathrm{AA}$ & 72,4 & 75,8 & 3,4 & 0,12 & Low \\
\hline 2 & AAL & 75,8 & 79,3 & 3,5 & 0,14 & Low \\
\hline 3 & AAYS & 58,6 & 65,5 & 6,9 & 0,17 & Low \\
\hline 4 & ANPB & 62,0 & 62,0 & 0,0 & 0,00 & Low \\
\hline 5 & CND & 55,1 & 62,0 & 6,9 & 0,15 & Low \\
\hline 6 & $\mathrm{DAB}$ & 51,7 & 68,9 & 17,2 & 0,36 & Medium \\
\hline 7 & DDFK & 58,6 & 62,0 & 3,4 & 0,08 & Low \\
\hline 8 & FZHP & 58,6 & 62,0 & 3,4 & 0,08 & Low \\
\hline 9 & FR & 68,9 & 72,4 & 3,5 & 0,11 & Low \\
\hline 10 & HNA & 58,6 & 72,4 & 13,8 & 0,33 & Medium \\
\hline 11 & JNS & 55,1 & 68,9 & 13,8 & 0,31 & Medium \\
\hline 12 & $\mathrm{KP}$ & 72,4 & 86,2 & 13,8 & 0,50 & Medium \\
\hline 13 & KAF & 65,5 & 79,3 & 13,8 & 0,40 & Medium \\
\hline 14 & MRIF & 44,8 & 48,2 & 3,4 & 0,06 & Low \\
\hline 15 & MAP & 68,9 & 75,8 & 6,9 & 0,22 & Low \\
\hline 16 & MHMA & 65,5 & 75,8 & 10,3 & 0,30 & Medium \\
\hline 17 & MNRF & 65,5 & 68,9 & 3,4 & 0,10 & Low \\
\hline 18 & MSAR & 65,5 & 68,9 & 3,4 & 0,10 & Low \\
\hline 19 & NAZ & 73,9 & 82,7 & 8,8 & 0,34 & Medium \\
\hline 20 & NAD & 68,9 & 68,9 & 0,0 & 0,00 & Low \\
\hline 21 & PRA & 68,9 & 75,8 & 6,9 & 0,22 & Low \\
\hline 22 & $\mathrm{RH}$ & 44,8 & 65,5 & 20,7 & 0,38 & Medium \\
\hline 23 & RDN & 72,4 & 82,7 & 10,3 & 0,37 & Medium \\
\hline 24 & SPPH & 65,5 & 62,0 & $-3,5$ & $-0,10$ & Low \\
\hline 25 & SN & 72,4 & 72,4 & 0,0 & 0,00 & Low \\
\hline 26 & VMRN & 55,1 & 75,8 & 20,7 & 0,46 & Medium \\
\hline 27 & ZL & 65,5 & 75,8 & 10,3 & 0,30 & Medium \\
\hline 28 & AZM & 55,1 & 62,0 & 6,9 & 0,15 & Low \\
\hline 29 & AT & 55,1 & 58,6 & 3,5 & 0,08 & Low \\
\hline 30 & $\mathrm{AAH}$ & 62,0 & 62,0 & 0,0 & 0,00 & Low \\
\hline 31 & $\mathrm{BN}$ & 75,8 & 75,8 & 0,0 & 0,00 & Low \\
\hline 32 & $\mathrm{CSN}$ & 51,7 & 72,4 & 20,7 & 0,43 & Medium \\
\hline 33 & DTYP & 41,3 & 44,8 & 3,5 & 0,06 & Low \\
\hline 34 & EKSA & 55,1 & 79,3 & 24,2 & 0,54 & Low \\
\hline 35 & FAA & 62,0 & 44,8 & $-17,2$ & $-0,45$ & Low \\
\hline 36 & FAM & 62,0 & 62,0 & 0,0 & 0,00 & Low \\
\hline 37 & HZA & 65,5 & 65,5 & 0,0 & 0,00 & Low \\
\hline 38 & KZKK & 51,7 & 65,5 & 13,8 & 0,29 & Low \\
\hline 39 & KAZ & 48,2 & 72,4 & 2,2 & 0,47 & Medium \\
\hline 40 & MHH & 68,9 & 65,5 & $-3,4$ & $-0,11$ & Low \\
\hline 41 & MSKR & 51,7 & 55,1 & 3,4 & 0,07 & Low \\
\hline 42 & MHM & 62,0 & 62,0 & 0,0 & 0,00 & Low \\
\hline 43 & MKM & 75,8 & 86,2 & 10,4 & 0,43 & Medium \\
\hline 44 & MMPA & 75,8 & 75,8 & 0.0 & 0,00 & Low \\
\hline 45 & MRF & 65,5 & 65,5 & 0.0 & 0,00 & Low \\
\hline 46 & NA & 65,5 & 58,6 & -6.9 & $-0,20$ & Low \\
\hline 47 & NSM & 72,4 & 82,7 & 10.3 & 0,37 & Medium \\
\hline 48 & NAK & 44,8 & 48,2 & 3.4 & 0,06 & Low \\
\hline 49 & RSM & 51,7 & 72,4 & 20.7 & 0,43 & Medium \\
\hline 50 & $\mathrm{RA}$ & 58,6 & 75,8 & 17.2 & 0,42 & Medium \\
\hline 51 & RSY & 48,2 & 55,1 & 6.9 & 0,13 & Low \\
\hline 52 & SPZ & 65,5 & 62,0 & -3.5 & $-0,10$ & Low \\
\hline 53 & $\mathrm{ZA}$ & 55,1 & 51,7 & -3.4 & $-0,08$ & Low \\
\hline 54 & ZAM & 65,5 & 72,4 & 6.9 & 0,20 & Low \\
\hline \multicolumn{2}{|c|}{ Averge } & 61,54 & 67,96 & 6.42 & 0,17 & Low \\
\hline
\end{tabular}


Implementation of Project Oriented Problem-Based Learning (POPBL) Model Integrated with STEM

Table 2. Paired Samples Statistics

\begin{tabular}{ccc|c|c|c}
\hline & & Mean & $N$ & Std. Deviation & Std. Error Mean \\
\hline \multirow{2}{*}{ Pair 1 } & Pretest & 61,5444 & 54 & 9,13646 & 1,24332 \\
\cline { 2 - 6 } & Post-test & 67,9630 & 54 & 10,10713 & 1,37541 \\
\hline
\end{tabular}

Table 3. Paired Samples Correlations

\begin{tabular}{lll|l|l}
\hline & $N$ & Correlation & Sig. \\
\hline Pair 1 & Pretest \& Post test & 54 &, 629 &, 000 \\
\hline
\end{tabular}

Table 4. Paired Samples Test

\begin{tabular}{|c|c|c|c|c|c|c|c|c|c|}
\hline & & \multicolumn{5}{|c|}{ Paired Differences } & \multirow[b]{3}{*}{$t$} & \multirow[b]{3}{*}{$d f$} & \multirow[b]{3}{*}{ Sig. (2-tailed) } \\
\hline & & \multirow[b]{2}{*}{ Mean } & \multirow{2}{*}{$\begin{array}{l}\text { Std. } \\
\text { Deviation }\end{array}$} & \multirow{2}{*}{$\begin{array}{l}\text { Std. } \\
\text { Error } \\
\text { Mean }\end{array}$} & \multicolumn{2}{|c|}{$\begin{array}{c}95 \% \text { Confidence } \\
\text { Interval of the } \\
\text { Difference }\end{array}$} & & & \\
\hline & & & & & Lower & Upper & & & \\
\hline Pair 1 & $\begin{array}{l}\text { Pretest - } \\
\text { Post test }\end{array}$ & $-6,41852$ & 8,33298 & 1,13397 & $-8,69298$ & $-4,14405$ & $-5,660$ & 53 &, 000 \\
\hline
\end{tabular}

Based on table 2, a summary of the results of the descriptive statistics is obtained from the two samples studied, namely pre-test and post-test values. The pre-test value obtained an average learning result or mean of 61.54 , while the Posttest obtained an average learning outcome of 67.96. The number of respondents or students used was 54 people. For the value, Deviation in the Pretest is 9.13 and Post-test is 10.72. Finally, Std. Error Mean for pre-test is 1.243, and the post-test is 1.375 . The average value of learning outcomes 67.96, it means that descriptively there is a difference in the average learning outcomes between pre-test and post-test. To prove whether this difference is significant, the results of the paired sample t-test in the output table "Paired Samples Test" need to be interpreted further.

The results of the correlation test of the two data can be seen in table 3. Table 3 shows that the correlation coefficient (Correlation) is 0.629 with a significance value (Sig.) Of 0.00 . Because of the Sig. $0.00<0.05$ probability, it is said that there is a relationship between the pre-test and post-test variables. The final step is to test whether the pretest and post-test data differ significantly or not. The hypothesis is then made. The first, $\mathrm{HO}=$ There is no average difference between the pre-test and post-test learning outcomes, which means there is no effect of using STEM integrated POPBL models in students' mastery of science concepts. Secondly, HA $=$ There is an average difference between the pre-test and post-test learning outcomes, which means that there is an effect of using the STEM integrated POPBL learning model in students' mastery of science concepts. The basis for decision making in the paired sample t-test based on the significance value (Sig.) Of the SPSS output results is as follows if the Sig. (2-tailed) $<0.05$, then $\mathrm{H} 0$ is rejected, and $\mathrm{HA}$ is accepted, but if the value is Sig. (2-tailed)> 0.05 , then $\mathrm{HO}$ is accepted, and HA is rejected.

Based on table 4, it is known that the Sig. (2-tailed) $0.000<0.05$, then $\mathrm{H} 0$ is rejected, and HA is accepted. Therefore, it can be concluded that there is an average difference between the pretest and posttest learning outcomes, which means that there is an effect of using the STEM integrated POPBL learning model in concept mastery. The table also contains information about the value of "Mean Paired Differences," which is equal to 6.41852. This value shows the difference between the average pretest learning outcomes and the posttest learning outcomes average or 61.5444 $67.9630=-6.41852$. This difference is between 8.69298 to -4.14405 (95\% Confidence Interval of the Difference Lower and Upper).

Based on the results of statistical tests, it can be seen that there is a significant difference between the students' pretest and posttest scores in mastering the science concept. However, even though they are significantly different, students' concept mastery using the POPBL model is still in the low category. Increasing students' mastery of science concepts is very important in achieving learning outcomes (Wiggins \& McTighe, 2005). One of the factors that might influence the improvement of mastery of the concept, which is not too big but significant, is that the topic of environmental pollution is considered easy but requires logical reasons and a deep understanding of some phenomena that occur (Valeiras, Nora; Godoy, A. Luis, 2007). Some stages in POPBL learning are not carried out well. The hope is that using the STEM integrated POPBL model can be 


\section{Eliyawati, Sanjaya, Ramdani}

used as a learning model that can improve students' cognitive abilities in conceptual mastery. The fact, the increase that occurs at the implementation stage is still in a low category. Still, it is significantly different, meaning that the STEM integrated POPBL model can be used as an alternative learning model that can improve students' mastery of science concepts or improve other students' abilities.

\section{Conclusion}

The STEM integrated POPBL model is a problem-based learning model with the final product in the form of projects related to STEM. This learning consists of 3 stages: Onset Stage, Execution Stage, and Closure Stage. The main research variable is measuring the increase in students' mastery of concepts on the topic of Environmental Pollution. The student concept emphasizes the onset stage in the case study dissemination phase. In this phase, students analyze the problems based on the articles provided by the teacher. The more they understand the material, the more critical the students are exploring existing problems and finding logical solutions to these problems. The results showed that there was a difference between the average pretest and posttest learning outcomes $(\mathrm{t}=-5,660$; $\mathrm{df}=53$; Sig. $(2$-tailed $)=0,000)$. This indicates an increase in junior high school students' mastery of science concepts after using the STEM integrated POPBL model. The increase in students' mastery of concepts using the STEM integrated POPBL model is still in the low category with an n-gain value $=0.17$. Even though it is still in the low category, the POPBL learning model with the STEM approach can be optimized to improve students' mastery of concepts and skills on other science topics.

\section{References}

Amarudin, C. H. (2020). Upaya Meningkatkan Hasil Belajar Mata Pelajaran IPA Melalui Penggunaan Pendekatan Keterampilan Proses (PKP) Siswa Kelas VI SD Negeri 2 Ciloa. Pedagogi: Jurnal Penelitian Pendidikan, 6(1).

Andanawarih, M., Diana, S., \& Amprasto, A. (2019). The implementation of authentic assessment through project-based learning to improve student's problem-solving ability and concept mastery of environmental pollution topic. In Journal of Physics:
Conference Series (Vol. 1157, No. 2, p. 022116).

Anderson, L. W., Krathwohl, D. R., Airasian, P. W., Cruikshank, K. A., Mayer, R. E., Pintrich, P. R., ... \& Wittrock, M. C. (2001). A taxonomy for learning, teaching, and assessing: A revision of Bloom's taxonomy of educational objectives, abridged edition. White Plains, NY: Longman.

Barbour, I. G. (1993). Ethics in an Age of Technology (No. 2, 1989-1991).

Devi, P. S., \& Bayu, G. W. (2020). Berpikir Kritis dan Hasil Belajar IPA Melalui Pembelajaran Problem Based Learning Berbantuan Media Visual. MIMBAR PGSD Undiksha, 8(2), 238-252.

Fraenkel. (2008). How to Design and Evaluate Research in Education Seventh Edition. United States: McGraw Hill International Edition.

Hasanah, N., Hasruddin, \& Yus, A. (2018). The Effect of Problem Based Learning Model on Students Science Process Skills. Research Gate, 370 .

Ibrahim, N., \& Halim, S. A. (2013). Implementation of project-oriented problembased learning (POPBL) in introduction to programming Course. PBL Across Cultures, 279

Kementerian Perindustrian Republik Indonesia. (2016). Industri Kreatif Bakal. Retrieved April 8, 2018, from http://www.kemenperin.go.id/artikel/5749/In dustriKreatif-Bakal

Knorr, W. R. (2019). Infinity and continuity: The interaction of mathematics and philosophy in antiquity.

Kumar, V., Kumar, U., \& Persaud, A. (1999). Building Technological Capability through Importing Technology: The Case of Indonesian Manufacturing Industry. Journal of Technology Transfer, 24, 81-96.

Lehmann, M., Christensen, P., Du, X., \& Thrane, M. (2008). Problem-oriented and projectbased learning (POPBL) as an innovative learning strategy for sustainable development in engineering education. 
European journal of engineering education, 33(3), 283-295.

Mahasneh, A. M., \& Alwan, A. F. (2018). The Effect of Project-Based Learning on Student-Teacher Self-efficacy and Achievement. International Journal of Instruction, 513.

Meehan, A., Lawlor, B., \& McLoone, S. (2014). On Project Oriented Problem Based Learning (POPBL) for a First-Year Engineering Circuits Project, 386-391. https://doi.org/10.1049/cp.2014.0719

Moesby, E. (2005). Curriculum development for project-oriented and problem-based learning (POPBL) with emphasis on personal skills and abilities. Global Journal of Engineering Education, 9(2), 121-128. Retrieved from http://wiete.com.au/journals/GJEE/Publish/v ol9no2/Moesby.pdf

Mohamed, M., Jubadi, W. M., \& Zaki, W. S. W. (2011). an Implementation of Popbl for Analog Electronics ( Bel10203 ) Course At the Faculty of Electrical and Electronic Engineering, Uthm. Journal of Technical Education and Training(JTET), 3(2), 45-54.

Pujani, N. M., Suma, K., Sadia, W., \& Wijaya, A. F. C. (2018). Applying Collaborative Ranking Tasks to Improve Students' Concept Mastery and Generic Science Skills. Jurnal Pendidikan IPA Indonesia, 7(3), 293-301.

Putri, A. U., Rusyati, L., \& Rochintaniawati, D. (2018). The Impact of Problem-Solving Model on Students' Concept Mastery and Motivation in Learning Heat Based on Gender. Journal of Science Learning, 1(2), 71-76.

Rahman, A., Khaeruddin, K., \& Ristiana, E. (2020). Pengaruh Model PBL Terhadap Kemampuan Berpikir Kritis dan Pemahaman Konsep IPA Siswa Kelas V SDN 30 Sumpangbita. Edumaspul: Jurnal Pendidikan, 4(1), 29-41.

Ramdani, A., Jufri, A., Jamaluddin, J., \& Setiadi, D. (2020). Kemampuan Berpikir Kritis dan Penguasaan Konsep Dasar IPA Peserta Didik. Jurnal Penelitian Pendidikan IPA, 6(1), 119-124.
Ruhizan, M. Y., Ramlee, M., \& Azami, Z. (2014). Promoting Creativity through ProblemOriented Project-Based Learning in Engineering Education at Malaysian Polytechnics: Issues and Challenges 2 Problem Formulation. Proceedings of the 8th WSEAS International Conference on Education and Educational Technology, 253-258.

Sadiku, M. N., Tembely, M., \& Musa, S. M. (2015). Engineering and Engineering Technology: What is the difference? International Journal of Engineering Technology And Computer Research, 3(4), 82-84.

Siswanto, J. (2020, January). Mempersiapkan Society 5.0 melalui Pembelajaran Fisika. In Prosiding SNPF (Seminar Nasional Pendidikan Fisika).

Valeiras, N., \& Godoy, L. A. (2007). Understanding environmental pollution concepts: a case study using school students in Argentina and Puerto Rico. International Journal of Environment and Pollution, 31(34), 342-358.

Wardani, P. S. (2017). The Effect of Problem Based Learning Instruction on Students Science Process Skills in Physics. Research Gate, 132;135.

Wan Nor Fadzilah, W. H., Nurazidawati, M. A., Oziah, O., Lilia, H., Mohammad Satar, R., Kamisah, O., \& Zanaton, I. (2016). Fostering students' 21st-century skills through project-oriented problem based learning (POPBL) in integrated STEM education program. Asia-Pacific Forum on Science Learning \& Teaching, 17(1), 60-77.

Wicaksono, A. G. (2020). Penyelenggaraan Pembelajaran IPA Berbasis Pendekatan STEM dalam Menyongsong Era Revolusi Industri 4.0. LENSA (Lentera Sains): Jurnal Pendidikan IPA, 10(1), 54-62.

Widiasari, N. K. R., \& Sumantri, M. (2020). Kooperatif Tipe Group Investigation Melalui Setting Lesson Study Terhadap Kompetensi Pengetahuan IPA. Jurnal Ilmiah Sekolah Dasar, 4(2), 165-175.

Wiggins, G. P., Wiggins, G., \& McTighe, J. (2005). Understanding by design. Ascd 


\section{Eliyawati, Sanjaya, Ramdani}

Wijayama, B. (2020). Peningkatan Hasil Belajar IPA dan Karakter Rasa Ingin Tahu Melalui Model Problem Based Learning Peserta Didik Kelas VI. Jurnal Kreatif: Jurnal Kependidikan Dasar, 10(2), 190-198.

Wulandari, T., Kadir, A., La Fua, J., \& Zainuddin, Z. (2020). Pengaruh Model Problem Based Learning Berbasis Multimedia Terhadap Kemampuan Berpikir Kritis dan Hasil Belajar IPA. KULIDAWA, 1(1), 29-34.

Yamin, Y., Permanasari, A., Redjeki, S., \& Sopandi, W. (2017, September). Application of model project-based learning on integrated science in water pollution. In Journal of Physics: Conference Series (Vol. 895, No. 1, p. 012153).

Yasin, R. M., \& Rahman, S. (2011). ProblemOriented Project Based Learning (POPBL) in promoting Education for Sustainable Development. Procedia - Social and Behavioral Sciences, 15, 289-293. https://doi.org/10.1016/j.sbspro.2011.03.08.

Zubaidah, S. (2017). Keterampilan Abad Ke-21: Keterampilan. ResearchGate, (June), 3. 